\title{
Review of studies on outdoor thermal comfort in warm humid climates: challenges of informal urban fabric
}

\author{
Modest Maurus Baruti ${ }^{1,2}$ (D) Erik Johansson ${ }^{1} \cdot$ Johnny Åstrand ${ }^{1}$ \\ Received: 22 May 2018 / Revised: 10 May 2019 / Accepted: 3 July 2019 /Published online: 19 July 2019 \\ (C) The Author(s) 2019
}

\begin{abstract}
In warm humid climate regions where majority of the population spend most of the time outdoors, an adequate outdoor thermal environment is crucial. A number of studies on outdoor thermal comfort in warm humid climates were carried out in the past decade. However, most of these studies focused on the formal urban fabric and left the informal urban fabric, where typically 30 to $85 \%$ of the population in developing countries resides, unattended. Theoretically, the informal urban fabric structure of towns/ cities poses many outdoor thermal environmental challenges, such as lack of air movement, high thermal stress and discomfort. This paper reviews previous research on outdoor thermal comfort in warm humid climates, and, particularly, it focuses on the relationship between outdoor thermal comfort and urban fabric as well as human thermal perception. Regarding the formal urban fabric, this review asserts that the thermal comfort range is higher in warm humid climates than in temperate climates and that thermal indices alone cannot predict thermal comfort; behavioural and psychological adaptation have proven to have a big impact on thermal perception. As for the informal urban fabric, only few studies have investigated the influence of the urban geometry and none has studied people's thermal perception of the outdoor thermal environment. To conclude, the article highlights practical challenges posed by the informal urban fabric in contrast to the formal urban fabric in terms of structure (morphology).
\end{abstract}

Keywords Outdoor thermal comfort · Warm humid climates · Thermal indices · Informal urban fabric · Informal settlements · Acceptable index temperature limits

\section{Introduction}

Outdoor thermal comfort studies are crucial for understanding people's response to their thermal environments. This understanding can set a basis for prediction of the outdoor thermal environment in urban areas. Warm humid climates are characterised by long periods of warm weather in which outdoor and semi-outdoor environments are considered more conducive than indoor environments especially when there is no air-conditioning. Contrary to cold and temperate climates, people in warm humid tropical climates, especially

Modest Maurus Baruti

modest.maurus_baruti@hdm.lth.se; mmbaruti@gmail.com

1 Housing Development \& Management, Department of Architecture and Built Environment, Lund University, P.O. Box 118, SE-22100 Lund, Sweden

2 School of Architecture, Construction Economics and Management, Ardhi University, P.O. Box 35176, Dar es Salaam, Tanzania those in developing countries, spend more time outdoors than indoors. Thus, a pleasant outdoor thermal environment is crucial for the well-being of urban dwellers. In addition, comfortable outdoor spaces have a significant bearing on the comfort perception of the indoor ambience (Ahmed 2003).

Several studies on outdoor thermal comfort with different objectives and methods of analysis have been carried out in warm humid tropical and subtropical regions. For example, in the humid subtropical region, studies by Chen et al. (2015), Cheng et al. (2012), Hirashima et al. (2016), Hwang and Lin (2007), Hwang et al. (2010), Li et al. (2016a), Lin et al. (2013), Lin (2009), Lin et al. (2011), Lin et al. (2012a), Lin et al. (2012b), Lin and Matzarakis (2008), Liu et al. (2016), Lucchese et al. (2016), Ng and Cheng (2012), Spagnolo and de Dear (2003), Watanabe et al. (2014), Xi et al. (2012) and Yang et al. (2013b) were carried out. In the tropical rainforest region, studies by Makaremi et al. (2012), Trindade da Silva and Engel de Alvarez (2015), Yang et al. (2013a) and Yang et al. (2013b) were carried out. In the tropical savanna, there are also studies, such as those of Johansson et al. (2018), Kruger et al. (2017) and Ndetto and Matzarakis (2016). The 
above-mentioned studies are the foundation and provide perspectives on the state of outdoor thermal comfort in warm humid tropical regions, especially in formal (planned) urban areas.

Urbanization in developing countries has contributed to rapid growth of informal urban areas. According to the UN Habitat (2016), one in eight people lives in slums globally, and, in developing countries, $30 \%$ of urban residents lived in poor informal settlements in 2014. In Tanzania, Lusugga Kironde (2006) comments that recent calculations based on property tax databases, which include properties in both planned and unplanned areas, indicate that over $80 \%$ of all buildings in the city of Dar es Salaam ${ }^{1}$ are situated in unplanned areas. Social, economic and environmental challenges facing informal urban areas occupied the research community for decades, whereas thermal comfort issues did not. Informal urban fabric structures and the outdoor thermal environment need special attention for analysis, as they are complex. According to Sobreira and Gomes (2001), the geometry of informal settlements does not consist of regularly distributed dwellings; in fact, they display a complex structure. In addition, parameters normally used to study the physical properties of the urban canopy layer in the formal urban fabric, such as height-to-width $(\mathrm{H} / \mathrm{W})$ ratio of streets, and street orientation might not directly apply in the majority of the informal urban fabrics.

The influence of the urban fabric on microclimate and outdoor thermal comfort in the warm humid tropical and subtropical regions is reported by several studies. In the humid subtropical regions, for example, studies by Assis and Frota (1999), Johansson et al. (2013), Kakon et al. (2009), Kakon et al. (2010), Lin et al. (2010), Sharmin et al. (2015), Tan et al. (2017), Yang et al. (2011) and Yang and Lin (2016) are available. In the tropical rainforest regions, examples of studies include those of Emmanuel and Johansson (2006), Emmanuel et al. (2007), Johansson and Emmanuel (2006) and Qaid and Ossen (2015), and, in the tropical savannah regions, studies of De and Mukherjee (2018), Ndetto and Matzarakis (2013), Rodríguez-Algeciras et al. (2016) and Yahia et al. (2018) exist. Most of these studies investigate the formal urban fabric of the cities characterised by a designed and coordinated pattern of streets that are different from the informal urban fabric. In addition, these studies found differences in terms of microclimate and outdoor thermal comfort between low-rise and high-rise building areas in the formal urban fabric context.

Regarding outdoor thermal comfort, studies of Chen and Ng (2012), Nikolopoulou (2011), Potchter et al. (2018) and Vanos et al. (2010) were carried out, and they focus on different aspects. For example, Vanos et al. (2010) focused on the physiology of human thermal comfort while exercising.

\footnotetext{
${ }^{1}$ Commercial capital and largest city of Tanzania in East Africa.
}

On the other hand, Nikolopoulou (2011) focused on thermal adaptation and approaches in understanding outdoor thermal comfort; Chen and Ng (2012) focused on the behavioural aspects of outdoor thermal comfort and Potchter et al. (2018) focused on approaches, methods and quantification of outdoor thermal perception in various climates.

This paper presents a review of studies on outdoor thermal comfort in warm humid tropical regions focusing on two major parts. The first part presents a review of outdoor thermal comfort studies based on a subjective assessment of the thermal environment using field surveys. The second part presents a review of studies, which focuses on the relationship between the urban fabric and measured or calculated outdoor thermal comfort. Subsequently, the review presents a general perspective of outdoor thermal comfort in warm humid climates and outlines challenges of the informal urban fabric. Although previous studies show that urban geometry is one of the key determinants of outdoor microclimate and consequently human thermal comfort, other studies show that the latter is more complex due to psychological and behavioural factors (Nikolopoulou 2011; Nikolopoulou and Steemers 2003). The assumption that findings in the formal urban fabric can be applicable in the informal urban fabric can lead to lack of interest to investigate the thermal environment and people's thermal perception of the latter. Knowledge on people's thermal perception in the informal urban fabric is necessary to inform urban designers and planners who are involved in upgrading of the informal urban fabric. In addition, understanding of coping strategies, thermal neutrality and thermal preference and acceptable comfortable ranges is necessary for understanding of the thermal environment in these places.

The review is limited to warm humid climates, and it sets the basis to point out the research gap for further studies. It focuses on the following Köppen groups by Kottek et al. (2006): the equatorial zone (A), which is often referred to as tropical, e.g. tropical savannah (Aw) and tropical rainforest (Af) as well as the warm temperate zone (C), e.g. humid subtropical (Cfa) and monsoon-influenced humid subtropical (Cwa). The study has excluded hot summer and warmsummer Mediterranean climates (Csa and $\mathrm{Csb}$ ). In addition, this review is limited to international peer-reviewed articles in the English language.

\section{Field studies on outdoor thermal comfort in warm-humid climates}

Table 1 presents a list of studies reviewed in this section. Since one of the aims of Table 1 is to compare results from different sub-climates of warm humid tropical climates, studies that used PET are listed first as they are the majority. All studies reviewed in this section include fieldwork in outdoor or semioutdoor environments consisting of simultaneous 
Table 1 Review of outdoor thermal comfort studies in warm humid tropical climates. Thermal indices: PET, physiologically equivalent temperature; SET* (OUT_SET*), standard effective temperature; UTCI, universal thermal climate index; ETU, universal effective temperature; $\mathrm{ET}^{*}$, effective temperature; $\mathrm{PT}$, perceived temperature; TOP, operative temperature; WBGT, wet bulb globe temperature; $T_{\mathrm{a}}$, air temperature ( $T_{\mathrm{a}}$ is not a thermal index but has been used in some studies)

\begin{tabular}{|c|c|c|c|c|c|c|c|c|c|c|c|c|}
\hline & \multirow[t]{2}{*}{ City, country } & \multirow[t]{2}{*}{ Source } & \multirow[t]{2}{*}{$\begin{array}{l}\text { Thermal } \\
\text { indices }\end{array}$} & \multicolumn{3}{|c|}{$\begin{array}{l}\text { Neutral index } \\
\text { temperature }\left({ }^{\circ} \mathrm{C}\right)\end{array}$} & \multicolumn{3}{|c|}{$\begin{array}{l}\text { Preferred index } \\
\text { temperature }\left({ }^{\circ} \mathrm{C}\right)\end{array}$} & \multicolumn{3}{|c|}{$\begin{array}{l}\text { Acceptable index temperature } \\
\text { ranges }\left({ }^{\circ} \mathrm{C}\right)\end{array}$} \\
\hline & & & & $\begin{array}{l}\text { Winter/ } \\
\text { cool }\end{array}$ & $\begin{array}{l}\text { Summer/ } \\
\text { warm }\end{array}$ & $\begin{array}{l}\text { All } \\
\text { year }\end{array}$ & $\begin{array}{l}\text { Winter/ } \\
\text { cool }\end{array}$ & $\begin{array}{l}\text { Summer/ } \\
\text { warm }\end{array}$ & $\begin{array}{l}\text { All } \\
\text { year }\end{array}$ & $\begin{array}{l}\text { Winter/ } \\
\text { cool }\end{array}$ & $\begin{array}{l}\text { Summer/ } \\
\text { warm }\end{array}$ & All year \\
\hline A & Tropical savanna (Aw & & & & & & & & & & & \\
\hline 1 & $\begin{array}{l}\text { Dar es Salaam, } \\
\text { Tanzania }\end{array}$ & $\begin{array}{l}\text { Ndetto and Matzarakis } \\
\text { (2016) }\end{array}$ & PET & - & 27 & - & - & - & - & - & $23.0-31.0$ & - \\
\hline \multirow[t]{2}{*}{2} & Guayaquil, Ecuador & Johansson et al. (2018) & PET & 21.9 & 26.9 & 25.7 & 15.5 & 18.6 & 17.5 & $\begin{array}{l}\text { Upper } \\
34.3\end{array}$ & $\begin{array}{l}\text { Upper } \\
25.3\end{array}$ & $\begin{array}{l}\text { Upper } \\
31.3\end{array}$ \\
\hline & & & SET* $^{*}$ & 20.5 & 24.5 & 24.3 & 17.7 & 23.3 & 18.6 & $\begin{array}{l}\text { Upper } \\
30.9\end{array}$ & $\begin{array}{l}\text { Upper } \\
25.3\end{array}$ & $\begin{array}{l}\text { Upper } \\
29.0\end{array}$ \\
\hline \multirow[t]{2}{*}{3} & $\begin{array}{l}\text { Rio de Janeiro, } \\
\text { Brazil }\end{array}$ & Kruger et al. (2017) & PET & - & - & - & - & & & - & & \\
\hline & & & UTCI & - & - & - & - & & & - & & \\
\hline B & \multicolumn{12}{|l|}{ Tropical rainforest (Af) } \\
\hline 1 & Singapore & Yang et al. (2013b) & PET & - & - & 28.1 & - & - & 25.2 & - & - & $24.0-30.0$ \\
\hline 2 & Vitoria, Brazil & $\begin{array}{l}\text { Trindade da Silva and Engel } \\
\text { de Alvarez (2015) }\end{array}$ & PET & - & - & - & - & - & - & - & - & $22.0-30.0$ \\
\hline 3 & Singapore & Yang et al. (2013b) & PET & - & - & 28.7 & - & - & 26.5 & - & - & $26.3-31.7$ \\
\hline 4 & Putra, Malaysia & Makaremi et al. (2012) & PET & - & - & - & - & & & - & & \\
\hline $\mathrm{C}$ & \multicolumn{12}{|c|}{ Humid subtropical (Cfa and Cwa) } \\
\hline 1 & Changsha, China & Yang et al. (2013b) & PET & - & - & 27.9 & - & - & 22.1 & - & - & $24.0-31.0$ \\
\hline 2 & Changsha, China & Liu et al. (2016) & PET & 14.9 & 23.3 & 18.2 & - & - & - & - & - & $15.0-22.0$ \\
\hline 3 & Shanghai, China & Chen et al. (2015) & PET & 22.4 & & & - & - & & $15.0-29.0$ & & \\
\hline 4 & Guangzhou, China & Li et al. (2016a, 2016b) & PET & 15.6 & & & - & - & & $18.1-31.1$ & & \\
\hline 5 & Sydney, Australia & $\begin{array}{l}\text { Spagnolo and de Dear } \\
\text { (2003) }\end{array}$ & PET & & & & - & - & & $21.5-32.4$ & - & \\
\hline 6 & Hong Kong & Cheng et al. (2012) & PET & 20.7 & 25.0 & & - & - & & & & $19.0-30.0$ \\
\hline 7 & $\begin{array}{l}\text { Sun Moon Lake, } \\
\text { Taiwan }\end{array}$ & Lin and Matzarakis (2008) & PET & & & 27.2 & & & & & & $26.0-30.0$ \\
\hline 8 & Taichung, Taiwan & Lin (2009) & PET & 23.7 & 25.6 & & 23.0 & 24.5 & & & & $21.3-28.5$ \\
\hline 9 & $\begin{array}{l}\text { Campo Grande, } \\
\text { Brazil }\end{array}$ & Lucchese et al. (2016) & PET & & & & & & & $21-27$ & & \\
\hline 10 & Yunlin, Taiwan & Lin et al. (2012) & PET & & & & & & & & & $21.3-28.5$ \\
\hline 11 & Hong Kong & Ng and Cheng (2012) & PET & & 28.1 & & & & & $14-16$ & $27.0-29.0$ & \\
\hline 12 & Chiayi, Taiwan & Lin et al. (2012a, 2012b) & PET & & & & & & & & $26.1-30.4$ & \\
\hline 13 & $\begin{array}{l}\text { Belo Horizonte, } \\
\text { Brazil }\end{array}$ & Hirashima et al. (2016) & PET & 15.9 & 27.7 & & 20.9 & 14.9 & & & & $19.0-27.0$ \\
\hline 14 & Chengdu, China & Zeng and Dong (2015) & PET & - & 24.4 & - & - & - & - & - & $20.0-29.5$ & - \\
\hline \multirow[t]{2}{*}{15} & Hong, Kong & Huang et al. (2017) & PET & & & 20.7 & & & & & & $16.4-25.2$ \\
\hline & & & UTCI & & & 22.7 & & & & & & $18.9-26.5$ \\
\hline 16 & Taichung, Taiwan & Hwang et al. (2010) & TOP & 22.8 & 28.2 & & & & & & & $19.0-31.8$ \\
\hline 17 & $\begin{array}{r}\text { Taichung, Yunlin, } \\
\text { Chiayi, Taiwan }\end{array}$ & Lin et al. (2011) & SET $^{*}$ & 28 & 29.3 & & 26.7 & 28.5 & & & & \\
\hline 18 & Taichung, Taiwan & Hwang and Lin (2007) & SET* $^{*}$ & & & 27.2 & & & 26.9 & & & $19.7-34.7$ \\
\hline 19 & Taichung, Taiwan & Lin et al. (2013) & WBGT & & & 23.2 & & & & & & $20.0-26.0$ \\
\hline 20 & Guangzhou, China & Xi et al. (2012) & SET $^{*}$ & & 24.0 & & & & & & & \\
\hline \multirow[t]{3}{*}{21} & Nagoya, Japan & Watanabe et al. (2014) & ETU & & 33.1 & & & & & & & \\
\hline & & & SET $^{*}$ & & 34.0 & & & & & & & \\
\hline & & & UTCI & & 28.9 & & & & & & & \\
\hline 22 & Dhaka, Bangladesh & Ahmed (2003) & $\mathrm{T}_{\mathrm{a}}$ & - & - & - & - & & & - & & \\
\hline
\end{tabular}


micrometeorological measurements and assessment of subjective thermal perception of people. Subjective thermal comfort data were recorded using questionnaires with questions on the thermal state of the subjects. Measurements included the four basic environmental parameters with an influence on thermal comfort, namely, air temperature, humidity and radiation, for calculation of the mean radiant temperature (MRT) ${ }^{2}$ and wind speed. The thermal comfort indices used in these studies are divided into two groups based on Blazejczyk et al.'s (2012) simple indices, i.e. operative temperature (TOP) ${ }^{3}$ and wet bulb globe temperature (WBGT). ${ }^{4}$ Indices based on heat budget models, i.e. physiologically equivalent temperature (PET) ${ }^{5}$ new effective temperature $\left(\mathrm{ET}^{*}\right){ }^{6}{ }^{6}$ standard effective temperature $\left(\mathrm{SET}^{*}\right)^{7}$, sometimes referred to as OUT_SET* when used outdoors, universal thermal climate index $(\mathrm{UTCI})^{8}$ and perceived temperature (PT), ${ }^{9}$ were used. Detailed descriptions of these indices are found in Blazejczyk et al. (2012), Johansson (2016) and Johansson et al. (2014).

Thermal comfort is defined as "that condition of mind which expresses satisfaction with the thermal environment" (ASHRAE 2004; Fanger 1972; ISO 2005) and no preference to be warmer or cooler (Fanger 1972). The concept of thermal comfort in outdoor environments is more complex than that in indoors as it encompasses large temporal and spatial variations (Johansson et al. 2018; Nikolopoulou et al. 2001) coupled with a great range of activities people are engaged in (Nikolopoulou et al. 2001). From the beginning of the last decade, several studies (Ahmed 2003; Hwang and Lin 2007; Lin 2009; Lin and Matzarakis 2008; Spagnolo and de Dear 2003) have focused on the causal linkage between biophysical environments and the subject's state of thermal comfort in warm humid climates. In these studies, different thermal indices were applied; some of the studies (Huang et al. 2017; Johansson et al. 2018; Kruger et al. 2017; Spagnolo and de Dear 2003; Watanabe et al. 2014) compared more than one

\footnotetext{
2 The uniform surface temperature of an imaginary black enclosure with which man (also assumed black body) exchanges the same heat by radiation as in the actual environment.

${ }^{3}$ This is an arithmetic average of MRT and $T_{\mathrm{a}}$ into a single index.

${ }^{4} \mathrm{~A}$ heat stress index calculated from dry-bulb temperature, wet-bulb temperature and black globe temperature.

${ }^{5}$ Thermal comfort index representing the air temperature of a standard indoor environment in which a person with standard indoor activity and clothing has the same skin and core temperature as in the actual outdoor environment.

${ }^{6}$ Thermal comfort index that represents the temperature of a standard environment in which a subject would experience the same skin wettedness and skin temperature as in the actual environment.

${ }^{7}$ Thermal comfort index that represents the temperature of a standard environment at $50 \%$ relative humidity for respondents wearing clothing standardized for the given activity in the real environment.

${ }^{8}$ Thermal comfort index representing the air temperature of a reference environment, which provides the same physiological response of a reference person as the actual environment.

${ }^{9}$ Thermal comfort index expressed as the air temperature in a standardised environment, which achieves the same predicted mean vote, PMV, as the real environment.
}

index. In addition, some studies (Ahmed 2003; Villadiego and Velay-Dabat 2014; Yin et al. 2012) did not use commonly known thermal indices; instead, air temperature was considered in the evaluation of the outdoor thermal comfort. It is worth to note that majority of studies carried out in warm humid tropical climates used at least one of the common thermal indices to evaluate respondents' thermal perception (Table 1).

Furthermore, different studies have investigated both respondents' thermal neutrality and preference. Some studies (Chen et al. 2015; Cheng et al. 2012; Huang et al. 2017; Hwang et al. 2010; Li et al. 2016a; Lin et al. 2013; Lin and Matzarakis 2008; Liu et al. 2016; Ndetto and Matzarakis 2016; Ng and Cheng 2012; Watanabe et al. 2014; Xi et al. 2012; Zeng and Dong 2015) investigated only thermal neutrality. Other studies (Hirashima et al. 2016; Hwang and Lin 2007; Johansson et al. 2018; Lin 2009; Lin et al. 2011; Spagnolo and de Dear 2003; Yang et al. 2013a) investigated both neutral and preferred temperature. In addition, majority of these studies determined thermally acceptable ranges for the outdoor environment in warm humid climates.

\section{Thermal neutrality}

The neutral temperature $\left(T_{\mathrm{n}}\right)$ is defined as the index temperature at which $50 \%$ of the sample voted "cooler than neutral" and 50\% voted "warmer than neutral" (Spagnolo and de Dear 2003). Studies (Lin 2009; Liu et al. 2016; Spagnolo and de Dear 2003) have found significant differences in thermal neutrality between seasons in warm humid climates. Neutral temperature variations between seasons observed in studies, which used PET as thermal index for winter and summer, respectively, are as indicated in Table 1. Subsequently, studies by Hirashima et al. (2016), Hwang et al. (2010), Johansson et al. (2018), Lin (2009), Lin et al. (2011) and Liu et al. (2016) compared neutral temperatures for two seasons and found that people had different thermal perception in each season. In the winter season, the neutral temperature was lower compared to that in the summer season. This shows that adaptation influences outdoor thermal comfort; thus, people in Taiwan have more tolerance to high temperature than lower temperature as they experience high temperature for a longer period of the year. The marginal difference in the neutral temperatures between hot and cool seasons is associated with the effect of seasonal adaptation on thermal comfort as a result of psychological and behavioural adaptation to variations in microclimate (Lin et al. 2011). On the same note, Hwang et al. (2010) found a variation of $6{ }^{\circ} \mathrm{C}$ between winter $\left(22.8^{\circ} \mathrm{C}\right)$ and summer $\left(28.2{ }^{\circ} \mathrm{C}\right)$ of neutral operative temperature (TOP) for respondents in Taichung, Taiwan. In addition, the study noticed that the neutral operative temperature follows the profile of the respective monthly mean air temperature. The findings confirm the relationship between mean monthly outdoor 
temperature and neutral air temperature, which was applied to develop the adaptive comfort model.

On the other hand, studies by Johansson et al. (2018) and Spagnolo and de Dear (2003) observed neutral temperature in the cool season being higher than in the warm season. In humid subtropical Sydney, this was associated with the fact that respondents ignored the warmth contributed by the winter clothing (Spagnolo and de Dear 2003). In the tropical savanna climate of Guayaquil, voting may be based on previous experience. That is, people were so tired of the uncomfortable thermal conditions of the wet (warm) season that they gave higher thermal perception votes than they did at similar thermal conditions during the dry (cool) season (Johansson et al. 2018).

Other studies (Huang et al. 2017; Hwang and Lin 2007; Spagnolo and de Dear 2003; Zhang et al. 2018) conducted a comparative analysis of thermal environment conditions between outdoor, indoor and semi-outdoor. Some of them found that the neutral standard effective temperature (SET*) in outdoor environments significantly exceeds the recommended value for indoor environments (Hwang and Lin 2007; Spagnolo and de Dear 2003). Hwang and Lin (2007) found higher levels of neutral temperature in comparatively warmer environments which supports the occurrence of thermal adaptation among respondents of semi-outdoor and outdoor environments. The neutral temperature for indoor, semi-outdoor and outdoor environments was $24.4,25.8$ and $27.2^{\circ} \mathrm{C} \mathrm{SET} *$, respectively. The variation of thermal neutrality between the two spaces reinforces the argument that spatial and temporal variations of microclimate present different thermal conditions and adaptation possibilities. Contrary to the previous studies, Zhang et al. (2018) found higher neutral temperatures indoors than in semi-outdoor areas in the rural areas of Guangdong, China. Neutral temperatures in indoor spaces were 24.0 and $19.7^{\circ} \mathrm{C}$ TOP in the warm and cool seasons, respectively. For semi-outdoor areas, neutral temperatures were 23.4 and $18.4{ }^{\circ} \mathrm{C}$ TOP in the warm and cool seasons, respectively.

\section{Thermal preference}

Preferred temperature is the temperature that people want (Lin 2009). In theory, preferred temperature depicts expectation of the respondents from the thermal environment they experience. In studies by Johansson et al. (2018), Lin et al. (2011) and Yang et al. (2013a), preferred temperatures were found to be lower than neutral temperature demonstrating the influence of expectation. This is true for outdoors, semi-outdoors and indoors. Hwang and Lin (2007) noticed that the preferred temperatures for both outdoors $\left(26.9{ }^{\circ} \mathrm{C} \mathrm{SET} *\right)$ and semioutdoors $\left(24.6^{\circ} \mathrm{C} \mathrm{SET} *\right)$ were 1.2 and $0.3{ }^{\circ} \mathrm{C}$ lower than the neutral temperature for outdoors and semi-outdoors, respectively. There are also seasonal differences. Lin (2009) found that preferred PET in both cool and hot seasons were slightly lower than the neutral temperature and the percentage of those who "prefer cooler" in the hot season is greater than that in the cool season for high SET* bins of $34-39^{\circ} \mathrm{C}$. This is due to the fact that the air temperature is higher in warm seasons (Lin et al. 2011). In one study in Belo Horizonte, Brazil, Hirashima et al. (2016) found the preferred temperature for winter and summer to be 20.9 and $14.9^{\circ} \mathrm{C}$, respectively. The study observed that preferred temperature of $14.9^{\circ} \mathrm{C}$ for summer is due to the sharp drop in the number of people wanting warmer conditions in hot season with the increase of the PET.

\section{Thermal acceptable ranges}

The ASHRAE Standard 55 defines that the thermal comfort range is the temperature range that is acceptable to at least $80 \%$ (normal condition) or $90 \%$ (strict condition) of people; that is, only $10 \%$ of users feel that this thermal comfort range is unacceptable (ASHRAE 2004). Thermally acceptable ranges in warm humid tropical climates bring into attention several observations. First, several studies (Johansson et al. 2018; Li et al. 2016a; Lin 2009; Lin et al. 2012b; Lin and Matzarakis 2008; Ndetto and Matzarakis 2016; Ng and Cheng 2012) found that the thermal acceptable ranges in these regions are higher compared to those in cold and temperate climate. In the study by Lin and Matzarakis (2008) in Sun Moon Lake, Taiwan, it was found that the thermal comfort range for $80 \%$ acceptability to be $21.6-35.4{ }^{\circ} \mathrm{C}$ PET. In other studies in warm humid tropical climates, using the same thermal index, PET, similar results of high thermally acceptable ranges were found as indicated in Table 1 . The comfort ranges are considerably higher compared to those in Glasgow in northern Europe where Kruger et al. (2013) found a range of 9-18 ${ }^{\circ} \mathrm{C}$ PET and in the Mediterranean coastal climate where Cohen et al. (2013) found a range of $20-25^{\circ} \mathrm{C}$ PET.

Several studies (Johansson et al. 2014; Knez and Thorsson 2006; Li et al. 2016a; Lin 2009; Lucchese et al. 2016) have also pointed out that people in different regions have different thermal requirements due to thermal adaptation. A comparative study (Makaremi et al. 2012) of local and international students in Putra, Malaysia, reveals that local respondents could feel comfortable at much higher PET values than the international students as adaptation, both psychological and physiological, plays significant role on outdoor thermal comfort. These findings reinforce the conclusion that culture and environmental attitude play a key role in influencing thermal perception and reinforce the need to link thermal comfort indices and emotional perception of the thermal environment (Knez and Thorsson 2008).

In addition, a comparative analysis of the sub-climates within the warm humid tropical climates, e.g. tropical savannah (Aw), humid subtropical (Cfa and Cwa) and tropical rainforest (Af), reveals that the humid subtropical climate 
has both comfort ranges of higher PET values and wider thermal comfort ranges than the rest (Table 2). This is brought about by the nature of each sub-climate. Both the tropical savannah and tropical rainforest climates have small variations in monthly average air temperature, whereas the humid subtropical climate has distinctly different warm and cold seasons. It is likely that the higher average monthly temperatures of Dar es Salaam explain the higher thermal comfort values of 23-31 ${ }^{\circ} \mathrm{C}$ PET (Ndetto and Matzarakis 2016) compared to Belo Horizonte's $19-27^{\circ} \mathrm{C}$ PET (Hirashima et al. 2016). Subtropical climate (Cfa) studies which involved more than one season of the year have the widest thermally acceptable ranges, for example Li et al. (2016a) in Guangzhou with 14 $28{ }^{\circ} \mathrm{C}$, Chen et al. (2015) in Shanghai with $4-28^{\circ} \mathrm{C}$ and Cheng et al. (2012)in Hong Kong with $16-29^{\circ} \mathrm{C}$.

\section{Adaptation to the thermal environment}

Adaptation is defined as "the gradual decrease of the organism's response to the repeated exposure to a stimulus" (Nikolopoulou 2011). It can be physiological, behavioural and psychological. Different types of adaptation may occur simultaneously $(\mathrm{Ng}$ and Cheng 2012). Behavioural adaptation is a type of adjustment to the environment, which includes change of clothing, activity level, posture, moving in space and diet. Results from the reviewed field studies demonstrate that individuals change clothing levels so as to achieve comfort and that a correlation exists between clothing and thermal index value (Lin et al. 2013; Lin 2009). In addition, studies show that there are notable differences within different warm humid tropical climates when it comes to clothing. In humid subtropical climates (Cfa), studies (Hwang et al. 2010; Lin et al. 2011, 2012b) show significant differences in clothing values associated with seasonal variations, where clothing insulation increased with decreasing temperature and vice versa. Contrary to the humid subtropical climate (Cfa), in tropical savanna (Aw) and tropical rainforest (Af), climate studies (Johansson et al. 2018; Makaremi et al. 2012; Ndetto and Matzarakis 2016) show that there were no differences in clothing values in different seasons of the year. These findings can be linked to the nature of the climate. The humid subtropical climate has pronounced summer and winter seasons whereas the tropical savannah and the tropical rainforest climates have no winter, but rather wet and dry periods, and annual temperature variations are small.

Other examples of adaptive behaviour include the tendency of people to move to shaded areas or to use umbrellas (Johansson et al. 2018; Li et al. 2016a; Tung et al. 2014; Watanabe and Ishii 2016; Yang et al. 2013a). This tendency involves seeking shade under trees or man-made shading devices (Johansson et al. 2018; Lin et al. 2013, 2012b). In humid subtropical Guangzhou, Li et al. (2016a, b) found that in spring, the residents preferred activity in the border space of sunlight and shade and in summer, the residents preferred activity in the sunshade. Also, Yang et al. (2013a, b) found that moving to shaded areas, such as trees/shelters, was preferred by $80.8 \%$ of the respondents followed by the use of umbrella which was preferred by $32.5 \%$. On studying gender differences in response to the outdoor thermal environment, Tung et al. (2014) noticed that both genders preferred moving to shaded areas as a primary adaptation method. Additionally, men preferred drinking a beverage while women preferred using an umbrella to release heat stress.

Table 2 A comparison of acceptable comfort ranges in sub-climates of warm humid climates based on PET

\begin{tabular}{|c|c|c|c|c|c|c|c|c|c|c|c|c|c|c|c|c|c|c|c|c|c|c|c|c|}
\hline & \multirow{2}{*}{ City, Country } & \multirow{2}{*}{ Source } & \multirow{2}{*}{\begin{tabular}{|l|}
$\begin{array}{l}\text { Acceptable } \\
\text { ranges }\left({ }^{\circ} \mathrm{C}\right)\end{array}$ \\
Winter \\
\end{tabular}} & \multirow{2}{*}{\begin{tabular}{|l|} 
index \\
Summer \\
\end{tabular}} & \multirow{2}{*}{$\begin{array}{l}\text { temperature } \\
\text { All year } \\
\end{array}$} & \multicolumn{19}{|c|}{ PET $\left({ }^{\circ} \mathrm{C}\right)$} \\
\hline & & & & & & 14 & 15 & 16 & 17 & 18 & 19 & 20 & 21 & 22 & 23 & 24 & 25 & 26 & 27 & 28 & 29 & 30 & 31 & 32 \\
\hline $\mathbf{A}$ & TROPICAL SAVANNA & & & & & & & & & & & & & & & & & & & & & & & \\
\hline 1 & Dar es Salaam, Tanzania & $\begin{array}{l}\text { Ndetto } \\
\text { Matzarakis,2016 and }\end{array}$ & - & $23.0-31.0$ & - & & & & & & & & & & & & & & & & & & & \\
\hline 2 & Guayaquil, Equador & Johansson et al., 2018 & Upper 34.3 & Upper 25.3 & Upper 31.3 & & & & & & & & & & & & & & & & & & & \\
\hline B & TROPICAL RAINFORE & EST (Af) & & & & & & & & & & & & & & & & & & & & & & \\
\hline 1 & Singapore & Yang et al., 2013b & - & - & $24.0-30.0$ & & & & & & & & & & & & & & & & & & & \\
\hline 2 & Vitoria, Brazil & $\begin{array}{l}\text { da Silva and de } \\
\text { Alvarez, 2015 }\end{array}$ & - & - & $22.0-30.0$ & & & & & & & & & & & & & & & & & & & \\
\hline 3 & Singapore & Yang et al., 2013b & - & - & $26.3-31.7$ & & & & & & & & & & & & & & & & & & & \\
\hline $\mathrm{C}$ & HUMID SUBTROPICA & L (Cfa \& Cwa) & & & & & & & & & & & & & & & & & & & & & & \\
\hline 1 & Changsha, China & Yang et al., 2013b & - & - & $24.0-31.0$ & & & & & & & & & & & & & & & & & & & \\
\hline 2 & Changsha, China & Liu et al., 2016 & - & - & $15.0-22.0$ & & & & & & & & & & & & & & & & & & & \\
\hline 3 & Shanghai, China & Chen et al., 2015 & $15.0-29.0$ & - & & & & & & & & & & & & & & & & & & & & \\
\hline 4 & Guangzhou, China & Li et al., 2016 & $18.1-31.1$ & - & & & & & & & & & & & & & & & & & & & & \\
\hline 5 & Sydney, Australia & $\begin{array}{l}\text { Spagnolo and de Dear, } \\
2003\end{array}$ & $21.5-32.4$ & - & & & & & & & & & & & & & & & & & & & & \\
\hline 6 & Hong Kong & Cheng et al., 2012 & - & - & $19.0-30.0$ & & & & & & & & & & & & & & & & & & & \\
\hline 7 & Sun Moon Lake, Taiwan & $\begin{array}{l}\text { Lin and Matzarakis, } \\
2008\end{array}$ & - & - & $26.0-30.0$ & & & & & & & & & & & & & & & & & & & \\
\hline 8 & Taichung, Taiwan & Lin, 2009 & - & - & $21.3-28.5$ & & & & & & & & & & & & & & & & & & & \\
\hline 9 & Campo Grande, Brazil & Lucchese et al., 2016 & $21-27$ & & & & & & & & & & & & & & & & & & & & & \\
\hline 10 & Yunlin, Taiwan & Lin et al., 2012 & & & $21.3-28.5$ & & & & & & & & & & & & & & & & & & & \\
\hline 11 & Hong Kong & Ng and Cheng, 2012 & $14-16$ & $27.0-29.0$ & & & & & & & & & & & & & & & & & & & & \\
\hline 12 & Chiayi, Taiwan & Lin et al., 2012 & - & $26.1-30.4$ & & & & & & & & & & & & & & & & & & & & \\
\hline 13 & Belo Horizonte, Brazil & Hirashim & - & & $19.0-27.0$ & & & & & & & & & & & & & & & & & & & \\
\hline 14 & Chengdu, China & Zeng and Dong, 2015 & - & $20.0-29.5$ & & & & & & & & & & & & & & & & & & & & \\
\hline 15 & Hong, Kong & Huang et al., 2017 & & & $16.4-25.2$ & & & & & & & & & & & & & & & & & & & \\
\hline & LEGEND & & & & & & Low & R LI & & & & & UPPEI & LIM & & & & & con & & ONE & & & \\
\hline
\end{tabular}


Psychological factors, such as past experience, expectations and autonomy, are believed to have a major impact on the thermal perception and may to a large extent explain the poor correlation between the thermal perception predicted by thermal indices and subjectively perceived thermal comfort (Nikolopoulou 2011; Nikolopoulou and Steemers 2003). It is worth to note that several studies (Ahmed 2003; Makaremi et al. 2012; Zeng and Dong 2015) have shown that the thermal history, which refers to the climate a person has experienced before entering the actual climate, influences the perception of the thermal environment. Thermal history can be everything from seasonal to only a few hours but can significantly affect respondent's perception of the thermal environment. It is observed in many studies that the length of time respondents spend outdoors is one of the important factors of adaptation. Ahmed (2003) noticed that the longer the people stay outdoors the higher their comfort range when compared to those who stay for a short period of time, and, thus, respondents who were exposed to outdoor environments with longer exposure were more comfortable. Conversely, Yang et al. (2013a) found that the time of exposure did not significantly affect the thermal sensation votes.

Autonomy, which means the degree of personal control, has been found to have a considerable impact on thermal perception in warm humid tropical environments. Lin et al. (2012a, b) discovered that when the interviewee possessed autonomy (that is, they could enter or leave the park freely), they attended activities in the plaza with superior tolerance of the thermal environment, even under uncomfortable conditions. This may be attributed to the presence of numerous choices of activities, a necessary factor for adaptation. Furthermore, Lin et al. (2013) observed that when people engage in outdoor leisure activities and can freely control the time, location and type of activities, they are more able to accept the conditions of the outdoor thermal environment. Johansson et al. (2018) found acceptance of higher values of SET* $\left(31^{\circ} \mathrm{C}\right)$ for respondents who were voluntary in a place when compared to those who were just passing by $\left(28^{\circ} \mathrm{C}\right)$. In contrast, Yang et al. (2013a) found that influence of the purpose of stay on the thermal sensation of respondents in the outdoor environment was insignificant.

\section{Influence of the formal urban fabric on outdoor thermal comfort}

As pointed out by Erell et al. (2010), despite the heterogeneity of the urban canopy in any real city, it is useful to describe the fabric of buildings and open spaces in terms of quantifiable measures that express its density or other physical properties that influence the micro-scale climate. The urban fabric reflects the morphological composition of physical elements within a certain area. It can be defined by indicators such as density, compactness, variation, fragment and cohesion ( $\mathrm{Li}$ et al. 2016b). In order to analyse the urban fabric and its influence on the outdoor thermal comfort, there is a need for an understanding of urban fabric descriptors at street level (urban canopy layer), which includes height-to-width $(\mathrm{H} / \mathrm{W})$ ratio, canyon axis orientation and sky-view factor (SVF). The mentioned urban fabric descriptors form the basis of discussion and analysis of outdoor thermal comfort at the urban level. Table 3 presents a summary of quantitative and qualitative results based on studies on the influence of the urban fabric on microclimate and outdoor thermal comfort.

\section{Influence of microclimatic variables on thermal perception}

A number of studies have investigated the influence of different microclimatic variables on thermal perception of people in warm humid climates. Results have shown that microclimatic variables vary in influence in different seasons and especially solar radiation, wind speed and air temperature have significant influence on thermal perception of people. Seasonality and the type of sub-climate within warm humid tropical climates can determine the influence of each variable.

\section{Solar radiation}

In warm humid tropical climates, studies (Hwang and Lin 2007; Lin 2009; Lin et al. 2011; Lin and Matzarakis 2008; Shih et al. 2017) have observed strong influence of solar radiation on respondents' thermal perception and found respondents to be more sensible to variations in global solar radiation $\left(R^{2}=0.92\right)$ than air movement $\left(R^{2}=0.79\right)$. Similarly, Shih et al. (2017) found that occupants' thermal perception in spaces was more influenced by solar radiation than wind speed. Notable seasonal differences on the influence of solar radiation were observed by Lin (2009) who found that MRT strongly influenced the number of people visiting the square in the hot season. Conversely, in the cool season, the $T_{\mathrm{a}}$ was the determining factor on the use of the square. In addition, Lin et al. (2011) observed that in both the warm and cold seasons, as MRT increases, the percentage of those who "prefer stronger sunshine" decreases and the percentage who "prefer weaker sunshine" increases. The study concludes that operative temperature, which is the combination of MRT and $T_{\mathrm{a}}$, strongly affects people's thermal perception.

\section{Air temperature}

The role of air temperature on the perception of thermal comfort in warm humid climates depends largely on the subclimate in question. For the humid subtropical climates with pronounced winter and summer seasons, studies have shown more significant influence of $T_{\mathrm{a}}$ in winter than in summer (Lin 
Table 3 Qualitative and quantitative results of studies on influence of urban fabric on outdoor thermal comfort in subclimates of warm humid tropical climates

\begin{tabular}{|c|c|c|c|c|c|}
\hline & City, country & Source & Method & $\begin{array}{l}\text { Thermal } \\
\text { indices }\end{array}$ & Qualitative and quantitative results \\
\hline A & \multicolumn{5}{|c|}{ Tropical savanna (Aw) } \\
\hline 1 & $\begin{array}{l}\text { Dar es Salaam, } \\
\text { Tanzania; }\end{array}$ & $\begin{array}{l}\text { Ndetto and } \\
\quad \text { Matzarakis (2013) }\end{array}$ & Simulation & PET & $\begin{array}{l}\text { East-west-oriented streets were having worse pedestrian thermal comfort compared to } \\
\text { north-south-oriented streets. Increase in building height to a maximum height of } \\
100 \mathrm{~m} \text { reduced both MRT and PET. }\end{array}$ \\
\hline 2 & $\begin{array}{l}\text { Dar es Salaam, } \\
\text { Tanzania }\end{array}$ & Yahia et al. (2018) & Simulation & PET & $\begin{array}{l}\text { Compact urban areas with high-rise buildings was having lower MRT and wind speed } \\
\text { while vice versa was true for low-rise areas. Low-rise informal urban areas are more } \\
\text { uncomfortable, and the shade seems an important factor than wind speed. Trees can } \\
\text { reduce PET up to } 14{ }^{\circ} \mathrm{C} \text {. }\end{array}$ \\
\hline 3 & $\begin{array}{l}\text { Camagüey, } \\
\text { Cuba }\end{array}$ & $\begin{array}{l}\text { Rodríguez-Algeciras } \\
\text { et al. (2016) }\end{array}$ & Simulation & PET & $\begin{array}{l}\text { Aspect ratio between } 1 \text { and } 1.5 \text { provides acceptable thermal environment for summer } \\
\text { and winter. Changing street orientation to } \mathrm{N}-\mathrm{S} \text { reduces heat stress in summer up to } \\
2 \mathrm{~h} \text { within the street. } \mathrm{E}-\mathrm{W} \text { street is uncomfortable throughout a day for } \mathrm{H} / \mathrm{W}=0.5 \text {. } \\
\text { Similarity of PET is noticed between } \mathrm{N}-\mathrm{S} \text { and intermediate orientations, e.g., } \\
\text { NE-SW and SE-NW. }\end{array}$ \\
\hline 4 & $\begin{array}{l}\text { Rajarhat } \\
\text { Newtown, } \\
\text { India }\end{array}$ & $\begin{array}{l}\text { De and Mukherjee } \\
\text { (2018) }\end{array}$ & Simulation & PET & $\begin{array}{l}\text { Orientation angle of } 30 \text { and } 60 \text { with canyon } \mathrm{H} / \mathrm{W} \text { ratio of } 2.5 \text { has a potential to reduce } \\
\text { the PET value by } 5-9{ }^{\circ} \mathrm{C} \text { during a mid-afternoon summer day. }\end{array}$ \\
\hline B & \multicolumn{5}{|c|}{ Tropical rainforest (Af) } \\
\hline 1 & $\begin{array}{l}\text { Colombo, } \\
\text { Sri-Lanka }\end{array}$ & $\begin{array}{l}\text { Johansson and } \\
\text { Emmanuel (2006) }\end{array}$ & Measurements & PET & $\begin{array}{l}\text { Sites with high } \mathrm{H} / \mathrm{W} \text { ratio found to have lower temperature during the day and higher } T_{\mathrm{a}} \\
\text { during night. Differences of up to } 20 \mathrm{~K} \text { were observed for surface temperature } \\
\text { between exposed and shaded areas. }\end{array}$ \\
\hline 2 & $\begin{array}{l}\text { Colombo, } \\
\text { Sri-Lanka }\end{array}$ & $\begin{array}{l}\text { Emmanuel and } \\
\text { Johansson (2006) }\end{array}$ & Measurements & - & $\begin{array}{l}\text { Urban-rural temperature differences were more significant and inter-urban differences } \\
\text { reached } 7 \mathrm{~K} \text {. Maximum temperature decrease with } \mathrm{H} / \mathrm{W} \text { ratio was observed. }\end{array}$ \\
\hline 3 & $\begin{array}{l}\text { Colombo, } \\
\text { Sri-Lanka }\end{array}$ & $\begin{array}{l}\text { Emmanuel et al. } \\
\text { (2007) }\end{array}$ & Simulation & PET & $\begin{array}{l}\text { Vegetation had positive impact on reduction of PET. Also, PET decreases with an } \\
\text { increase of H/W ratio to around } 10{ }^{\circ} \mathrm{C} \text {. Street orientation was found to have minor } \\
\text { effect on PET. }\end{array}$ \\
\hline 4 & $\begin{array}{l}\text { Putrajaya, } \\
\quad \text { Malaysia }\end{array}$ & $\begin{array}{l}\text { Qaid and Ossen } \\
\quad(2015)\end{array}$ & $\begin{array}{l}\text { Measurement } \\
\text { and } \\
\text { simulations }\end{array}$ & - & $\begin{array}{l}\text { An aspect ratio of } 2-0.8 \text { within asymmetrical canyons reduces the temperature of } \\
\text { surfaces by } 10 \text { to } 14^{\circ} \mathrm{C} \text { and } T_{\mathrm{a}} \text { by } 4.7^{\circ} \mathrm{C} \text {. Asymmetrical streets perform better than } \\
\text { low symmetrical streets in facilitating wind flow and reducing MRT. The air } \\
\text { temperature was reduced due to long hours of shading that reached up to } 4 \mathrm{~h} \text { from } \\
\text { the northeast buildings. }\end{array}$ \\
\hline $\mathrm{C}$ & \multicolumn{5}{|c|}{ Humid subtropical (Cfa and Cwa) } \\
\hline 1 & $\begin{array}{l}\text { Dhaka, } \\
\text { Bangladesh }\end{array}$ & Kakon et al. (2009) & $\begin{array}{l}\text { Measurement } \\
\text { and } \\
\text { simulations }\end{array}$ & THI & $\begin{array}{l}\text { Street canyons with high SVF had higher solar radiation than those with low SVF. } \\
\text { Deep canyons (low SVF) were } 3.5-6^{\circ} \mathrm{C} \text { cooler than shallow canyons. THI was } \\
\text { above the defined uncomfortable range. }\end{array}$ \\
\hline 2 & $\begin{array}{l}\text { Taichung, } \\
\text { Taiwan }\end{array}$ & Lin et al. (2010) & $\begin{array}{l}\text { Measurement } \\
\text { and } \\
\text { simulation }\end{array}$ & PET & $\begin{array}{l}\text { In highly shaded areas, PET was }<22^{\circ} \mathrm{C} \text { while in barely shaded areas probability of } \\
\text { PET }<22{ }^{\circ} \mathrm{C} \text { was only } 70 \% \text {. Thermal comfort during summer was } 50 \text { and } 20 \% \text { in } \\
\text { highly and barely shaded areas, respectively. High SVF leads to discomfort in } \\
\text { summer and low SVF leads to discomfort in winter. }\end{array}$ \\
\hline 3 & $\begin{array}{l}\text { Dhaka, } \\
\text { Bangladesh }\end{array}$ & Kakon et al. (2010) & $\begin{array}{l}\text { Measurement } \\
\text { and } \\
\text { simulation }\end{array}$ & THI & $\begin{array}{l}\text { Increase in building's height in a street canyon leads to lower SVF, less incoming solar } \\
\text { radiation, lower mean radiant temperature and lower } T_{\mathrm{a}} \text {. }\end{array}$ \\
\hline 4 & $\begin{array}{l}\text { Shanghai, } \\
\text { China }\end{array}$ & Yang et al. (2011) & $\begin{array}{l}\text { Measurement } \\
\text { and } \\
\text { simulation }\end{array}$ & PET & $\begin{array}{l}\text { An increase of } 0.4 \text { in surface albedo lowered } T_{\mathrm{a}} \text { at pedestrian level by } 0.2-0.4{ }^{\circ} \mathrm{C} \text { but } \\
\text { increased MRT by } 8-14{ }^{\circ} \mathrm{C} \text { during the day. Increase of vegetation reduces MRT by } \\
12-24 \text { and } 11-47{ }^{\circ} \mathrm{C} \text { for grass and trees, respectively. PET can be reduced by } 2-20 \\
\text { and } 5-20{ }^{\circ} \mathrm{C} \text { for grass and trees scenario, respectively. }\end{array}$ \\
\hline 5 & $\begin{array}{l}\text { Sao Paulo, } \\
\text { Brazil }\end{array}$ & $\begin{array}{l}\text { Johansson et al. } \\
\quad(2013)\end{array}$ & Simulation & TEP & $\begin{array}{l}\text { MRT was higher in low-rise buildings compared to high-rise areas. Addition of veg- } \\
\text { etation reduces the surface temperature by up to } 13^{\circ} \mathrm{C} \text { in low-rise areas. TEP can be } \\
\text { reduced by } 6 \text { and } 8^{\circ} \mathrm{C} \text { by adding vegetation in high- and low-rise areas, respec- } \\
\text { tively. }\end{array}$ \\
\hline 6 & $\begin{array}{l}\text { Dhaka, } \\
\text { Bangladesh }\end{array}$ & $\begin{array}{l}\text { Sharmin et al. } \\
\quad(2015)\end{array}$ & $\begin{array}{l}\text { Measurement } \\
\text { and } \\
\text { simulation }\end{array}$ & $\mathrm{Ta}$ & $\begin{array}{l}\text { Deeper urban canyon was having } 6.2^{\circ} \mathrm{C} \text { lower temperature than shallow canyons. } \\
\text { Globe temperature, MRT and TOP showed positive and strong correlation with SVF } \\
\text { and negative correlation with H/W ratio. }\end{array}$ \\
\hline 7 & Tainan, Taiwan & $\begin{array}{l}\text { Yang and Lin } \\
\quad(2016)\end{array}$ & $\begin{array}{l}\text { Measurement } \\
\text { and } \\
\text { simulation }\end{array}$ & PET & $\begin{array}{l}\text { Observed that aspect ratio of } 3 \text { can be considered as a threshold to outdoor thermal } \\
\text { comfort. Also, planting trees is the most effective way of reducing the (PET) - by up } \\
\text { to } 15.2^{\circ} \mathrm{C} \text {. Improvement of design of outdoor spaces has a potential to reduce the } \\
\text { frequency of heat stress from } 79.7 \text { to } 40.5 \% \text {. }\end{array}$ \\
\hline 8 & $\begin{array}{l}\text { Guangzhou, } \\
\text { China }\end{array}$ & $\begin{array}{l}\text { Zhang et al. } \\
\text { (2017) }\end{array}$ & Simulation & SET & $\begin{array}{l}\text { Street orientation has the largest contribution on SET at the pedestrian level of street } \\
\text { canyons for a typical summer day. SE-NW-oriented street canyon provides better } \\
\text { thermal comfort conditions than N-S or E-W-oriented. Contrary to previous } \\
\text { studies, the N-S-oriented street canyons had a higher SET and worse comfort con- } \\
\text { ditions in summer than the E-W-oriented street canyons due to wider spacing of the } \\
\text { buildings for the N-S-oriented street canyon as per sunshine requirements. MRT and } \\
\text { wind speed play key roles in pedestrian thermal comfort. }\end{array}$ \\
\hline 9 & Hong Kong & Tan et al. (2017) & $\begin{array}{l}\text { Measurement } \\
\text { and } \\
\text { simulation }\end{array}$ & PET & $\begin{array}{l}\text { Influence of vegetation (road side trees) was noted in low-SVF (0.2) areas under cloudy } \\
\text { conditions where PET was lowered to acceptable level of } 29^{\circ} \mathrm{C} \text { from approximately } \\
35-39^{\circ} \mathrm{C} \text {. Also, in exposed PET close to } 46.3{ }^{\circ} \mathrm{C} \text { was reduced to } 37.6^{\circ} \mathrm{C} \text { beneath } \\
\text { the tree canopy under cloudy conditions. }\end{array}$ \\
\hline
\end{tabular}


et al. 2011). According to Villadiego and Velay-Dabat (2014), people in the warm humid tropical savannah, which is dominated by small diurnal and yearly variations of air temperature, are highly sensitive to very small variations in air temperature. The study by Zeng and Dong (2015) in Chengdu, China, noticed strong connection between $T_{\mathrm{a}}$ and thermal perception votes of respondents who were located in shade; conversely, MRT and PET, which are significantly affected by solar radiation, were less important.

\section{Air movement}

Several studies (Ahmed 2003; Makaremi et al. 2012; Ng and Cheng 2012; Yin et al. 2012) investigated the influence of air movement on the thermal perception of respondents in warm humid tropical climates. Both Ahmed (2003) and Ng and Cheng (2012) found increased air movement to be an important factor in mitigating the heat stress in the urban area and the percentage of respondents that expressed neutral thermal perception increased gradually with increased air movement. The study suggests that lower temperature and higher wind speed can create a thermally neutral environment and alleviate the heat stress in summer. On similar grounds, Yin et al. (2012) found that the influence of wind on thermal perception was stronger in the shaded areas than in sunny areas, as shade tends to reduce the radiant heat gained by the human body as compared to a fully exposed location. Despite the fact that Makaremi et al. (2012) found significant differences regarding the wind perception of local and international students, both groups preferred an increase of the wind speed for reduction of thermal stress.

\section{Influence of urban fabric on microclimate variations}

Several studies (Emmanuel and Johansson 2006; Emmanuel et al. 2007; Johansson and Emmanuel 2006; Johansson et al. 2013, 2018; Kakon et al. 2009; Sharmin et al. 2015) have examined the influence of the urban fabric on the microclimate within urban canyons in different neighbourhoods in warm humid tropical climates. In the tropical rainforest climate of Colombo, Sri Lanka, Emmanuel and Johansson (2006) found that urban-rural temperature differences were more significant by day than by night. Both cool and heat islands were observed during daytime, and inter-urban differences reached $7 \mathrm{~K}$, as most of the urban sites were cooler than the rural station. Furthermore, Johansson and Emmanuel (2006) showed that during a clear day, calculated PET values for all sites were generally above the assumed upper comfort limit of $33{ }^{\circ} \mathrm{C}$ during daytime, and, thus, thermal comfort was poor. On an overcast day, however, PET values varied less between sites both by day and by night and it did not go beyond assumed thermal comfort limits.
A difference in the morphological structure of urban areas presents different influences on microclimate, especially on shade and wind patterns. Compact urban forms with high buildings create deep street canyons with high $\mathrm{H} / \mathrm{W}$ ratios. Such streets provide good shade (low MRT) whereas lowrise areas with low $\mathrm{H} / \mathrm{W}$ ratios are exposed to the sun and result in high MRT (Emmanuel and Johansson 2006; Johansson and Emmanuel 2006; Emmanuel et al. 2007; Johansson et al. 2013; Yahia et al. 2018).

The prevailing wind direction and the surrounding buildings heavily influence wind patterns (Yang et al. 2011). In general, high $\mathrm{H} / \mathrm{W}$ ratios lead to low wind speeds whereas low $\mathrm{H} / \mathrm{W}$ ratio allows higher wind speeds (Yahia et al. 2018). Wide streets result in higher wind speeds (Emmanuel and Johansson 2006). Variations in building height play a role in creating higher turbulence around high-rise buildings, thus enhancing urban ventilation (Emmanuel et al. 2007; Sharmin et al. 2015). Parallel arrangement of buildings combined with setbacks to increase the distance between buildings (lowering the $\mathrm{H} / \mathrm{W}$ ratio) facilitates and increases the wind speed (Emmanuel et al. 2007; Kakon et al. 2009). Moreover, asymmetrical aspect ratios may increase wind flow in urban canyons when tall buildings confront wind direction (Qaid and Ossen 2015).

\section{Effect of aspect $(H / W)$ ratio on outdoor thermal comfort}

The aspect ratio is a physical factor of urban canyons, which affects the magnitude of urban heat islands and affects microclimatic and outdoor thermal comfort conditions (Qaid and Ossen 2015). Several studies (Ahmed 1994; Emmanuel and Johansson 2006; Emmanuel et al. 2007; Qaid and Ossen 2015; Rodríguez-Algeciras et al. 2016; Yang and Lin 2016; Zhang et al. 2017) investigated the influence of aspect ratio on the microclimate and consequently outdoor thermal comfort at pedestrian level in warm humid climates. Both Ahmed (1994) in Dhaka, Bangladesh, and Emmanuel et al. (2007) in Colombo, Sri Lanka, found that the enhancement of shade in the medium and high density urban settings showed a positive effect on the thermal comfort. Emmanuel et al. (2007) found that daytime PET values decrease with increasing $\mathrm{H} / \mathrm{W}$ ratios; it leads to a decrease of around $10^{\circ} \mathrm{C}$ PET for the high-density case. In Singapore, Yang and Lin (2016) observed that an aspect ratio of three could be considered as a threshold to achieve outdoor thermal comfort. In a study conducted in Dar es Salaam, Yahia et al. (2018) noticed that spaces between buildings in low-rise areas without vegetation are the most stressful spots (PET varies from 40 to $47{ }^{\circ} \mathrm{C}$ ) when compared to those with less vegetation. Similar results were found by Johansson and Yahia (2012) who pointed out that the thermal conditions in Guayaquil, Ecuador, could be significantly improved (about $10{ }^{\circ} \mathrm{C}$ PET) by providing 
shading through trees or shading devices. Since high H/W ratios decrease the daytime temperature but increase the nocturnal air temperature, Johansson and Emmanuel (2006) pointed out that appropriate $\mathrm{H} / \mathrm{W}$ ratios depend on the type of the neighbourhood, as a higher nocturnal temperature may be more acceptable in commercial areas than in residential ones. Several studies (De and Mukherjee 2018; Kakon et al. 2010; Zhang et al. 2017) have found that an increase in aspect ratio leads to a reduction of PET and consequently a decrease of thermal discomfort although it is difficult to bring it down within the comfort range at 2:00 pm.

\section{The effect of SVF on outdoor thermal comfort}

The sky view factor (SVF) is one of the commonly used urban fabric descriptors. It represents the ratio at a point in space between the visible sky and a hemisphere centred over the analysed location (Oke 1981). The SVF includes the buildings along the urban canyon and other objects, such as trees, and it can also be used in street intersections. As for other climates, studies (Chen and Ng 2012; Johansson et al. 2013; Kakon et al. 2009, 2010; Lin et al. 2010; Qaid and Ossen 2015; Rodríguez-Algeciras et al. 2016; Tan et al. 2017) in warm humid tropical climates have pointed out the influence of SVF on both microclimate and outdoor thermal comfort.

Studies (Kakon et al. 2009, 2010) found that thermal comfort (expressed as the temperature humidity index, THI) decreases with decreasing SVF. Similarly, Yahia et al. (2018) found a strong linear relationship $\left(R^{2}=0.97\right)$ between the area-averaged SVF determined by ENVI-met and the average PET at $2 \mathrm{~m}$. Similar relationship between SVF and $T_{\mathrm{a}}$ were found by Chen and Ng (2012) in humid subtropical Hong Kong and expresses the fact that the higher the SVF (the more open a site is to the sky) the more stressful is the thermal environment. In humid subtropical climates, with pronounced summer and winter seasons, it was observed that areas with low SVF result in improved comfort levels in summer but worsened thermal conditions in winter (Lin et al. 2010; Rodríguez-Algeciras et al. 2016).

Previous studies mentioned above linked SVF to people's perception of outdoor thermal environment; however, Krüger et al. (2011) noted that SVF, when analysed as an isolated parameter, is not able to accurately predict the thermal conditions of a particular site during daytime since incoming solar radiation has a stronger effect on MRT. For accurate results, the study suggests a combined analysis of the SVF and the solar trajectory and not SVF alone.

\section{Effect of canyon axis orientation on outdoor thermal comfort}

Canyon axis orientation is one of the important factors affecting the thermal environment of a street as observed in several studies in warm humid and other climates (De and Mukherjee 2018; Johansson 2006; Kakon et al. 2010; Ndetto and Matzarakis 2013; Rodríguez-Algeciras et al. 2016, 2017; Zhang et al. 2017). A simulation study by Johansson (2006) in Colombo, Sri Lanka, showed that for $\mathrm{H} / \mathrm{W}$ ratios below 0.6, the influence of street orientation is marginal. However, for aspect ratios higher than that, north-south-oriented streets are more comfortable than east-west-oriented streets. The finding that north-south streets are more comfortable was confirmed by the study of Ndetto and Matzarakis (2013) in Dar es Salaam, Tanzania, and by Rodríguez-Algeciras et al. (2017) in Camagüey, Cuba. Johansson (2006) concluded that to achieve a noticeable improvement in outdoor thermal comfort in the climate of Colombo, east-west streets would need to be very deep, at least $\mathrm{H} / \mathrm{W}=4$, whereas north-south-oriented streets would need to have an $\mathrm{H} / \mathrm{W}$ ratio of at least 2. In Rajarhat Newtown, India, De and Mukherjee (2018) found that optimizing the orientation and canyon aspect ratio might reduce the thermal discomfort by a reduction of PET values of $5-10{ }^{\circ} \mathrm{C}$ during the most critical period of the day.

\section{Challenges in the informal urban areas}

The discussions in the previous sections focused on outdoor thermal comfort studies conducted in the formal urban fabric, which is the typical character of most of the developed world where most of the research has been carried out. Little is known on the subject of outdoor thermal comfort in informal settlements-also called slums, squatter settlements or shantytowns - and in this paper referred to as the informal urban fabric. These types of settlements mostly occur in developing and newly industrialized countries. According to Kombe (1995), too many, including bureaucrats and politicians see informal settlements as a transient phenomenon and an outcome of economic hardship which will ease once the national economy improves. However, this belief has proven to be a myth rather than reality. According to Hofmann et al. (2008), informal settlements are defined (1) as areas where groups of housing units have been constructed on land that the occupants have no legal claim to or occupy illegally and (2) as unplanned settlements and areas where housing is not in compliance with the current planning and building regulations (unauthorized housing). Studies by Huchzermeyer (2004) and Richards et al. (2006) have shown that in developing countries, informal urban areas are there to stay for the next decades and beyond.

In developing countries, urbanization is advancing in a very high speed, predominantly in the urban fringe (UN Habitat 2016). This rapid urbanization is directly linked to the growth of informal settlements in Latin America, East Asia and Sub-Saharan Africa. According to AugustijnBeckers et al. (2011), important reasons for informal 
settlement growth are the weakness of statutory planning and the strong rural-urban migration. The latter, in combination with natural population growth, is leading to substantial urban population growth.

Challenges of informal neighbourhoods span from social, economic and environmental; however, the discussion in this paper focuses on decreased outdoor thermal comfort. It is an established fact that areas with poor urban design will experience decreased thermal comfort in hot/warm climates which has a negative effect on people's well-being and may have serious consequences for health (Johansson 2006). Improvement of the outdoor environment in the informal urban fabric in terms of microclimate and outdoor thermal comfort will not only create a better outdoor environment but also improve the indoor environment.

\section{Outdoor thermal comfort in informal urban fabric}

Only a few studies (Kakon et al. 2009; Yahia et al. 2018; Sharmin et al. 2015) have compared the outdoor microclimate and the thermal environment between the informal urban fabric and the formal urban fabric in warm humid climates. In Dhaka, Bangladesh, Kakon et al. (2009) compared the informal urban area of Siddeswari $(\mathrm{H} / \mathrm{W}=1.88)$ with the formal areas of Motijheel and Dhanmondi with $\mathrm{H} / \mathrm{W}$ ratios of 0.47 and 0.92 , respectively. The researcher found that THI reached up to $35.3{ }^{\circ} \mathrm{C}$ in Dhanmondi, $34.7{ }^{\circ} \mathrm{C}$ in Siddeswari and $34.5^{\circ} \mathrm{C}$ in Motijheel, thus being higher (> $26^{\circ} \mathrm{C}$ ) than acceptable comfort limits in all canyons. In terms of thermal comfort, it was noted that Dhanmondi is the most uncomfortable (hottest) and Motijheel is more uncomfortable than Siddeswari due to the fact that in Siddeswari the duration of strong solar radiations is short and it has the lowest SVF. In comparison, in another simulation study in Dar es Salaam, Tanzania, Yahia et al. (2018) compared maximum PET of the informal urban area of Manzese (mostly single-story compact dwellings) with three formal urban areas, Upanga (mainly medium-rise, green area), Kariakoo (very dense area with 2-10-story buildings) and the city centre (medium- to highrise buildings). The study found that informal Manzese was the most uncomfortable area with PET values above the comfort range for Dar es Salaam of 23-31 ${ }^{\circ} \mathrm{C}$ (Ndetto and Matzarakis 2016). Sharmin et al. (2015) compared a traditional area (informal with $\mathrm{H} / \mathrm{W}=1-4)$ with planned areas $(\mathrm{H} / \mathrm{W}=$ 1.2-2.75). In this study, it was found that the informal urban areas, which have variable urban forms with irregular plot sizes and building heights, responded positively to the synoptic climate, while the planned areas, with uniform plot sizes and height, showed a tendency to develop a daytime urban heat island effect. Despite the fact that the morphological structure of the informal urban fabric in these studies differs, it could be concluded from the studies that low-rise compact informal urban fabrics morphologically presents a challenging outdoor thermal environment.

Apart from the calculated thermal comfort in the abovementioned studies in informal settlements, little is known on the subjective thermal perception of urban dwellers residing in these settlements. Most of the studies on outdoor thermal comfort have dealt with either recreational spaces (such as parks, squares and open spaces) or transient spaces (such as train stations, bus terminals, semi-outdoor spaces and streets). Only a few studies (Li et al. 2016a) have investigated the outdoor thermal environment in the areas where people live. Knowledge of people's thermal perception of outdoor thermal comfort in informal settlements is important as these areas are places for living and working. A review of different approaches for the informal urban fabric upgrading has been discussed by Abbott (2002); however, none of the approaches have taken into consideration integrated issues of microclimate and thermal comfort of the urban dwellers who live in these areas.

\section{Conclusion}

The objective of this paper was to review studies on outdoor thermal comfort in warm humid climates and to highlight challenges brought up by rapid urbanization in terms of thermal comfort in the informal urban fabric. A number of studies presented in this review have shown the development and growing interest of research on outdoor thermal comfort in warm humid climates in the past decade. Although results vary between studies, it can be concluded that the levels of neutral temperature and thermal comfort ranges are higher in warm humid climates than in colder climates. There is also a difference between tropical rainforest (Af) and tropical savannah (Aw) on one hand and humid subtropical (Cfa) on the other. The latter, which is characterised by pronounced summer and winter seasons, has a larger difference between seasons as regards the neutral temperature and the comfort range than the former two, which are characterised by small annual differences. Despite the dweller's higher tolerance to heat, it is difficult to achieve thermally comfortable conditions during the hottest part of the day in the tropical rainforest and tropical savannah climates, as well as during the warm season of the humid subtropical climates. Shade through buildings (high H/ $\mathrm{W}$ ratio) and/or shading devices or vegetation is necessary to reduce heat stress. In addition, ventilation should be enhanced.

Most of the studies in this review have focused on transient spaces (e.g. bus and train stations) and recreational areas (e.g. parks and squares) of the formal urban fabric, which represents a small portion of the cities. In developing countries, the mentioned areas of the planned formal sector might not represent as much of the city structure as the informal urban fabric does. This review found that only few studies (Kakon 
et al. 2009; Sharmin et al. 2015; Yahia et al. 2018) compared formal and informal urban fabric in terms of outdoor thermal comfort. Moreover, none of the mentioned studies has investigated people's perception of outdoor thermal comfort in the informal urban fabric. Further studies to unveil the urban dwellers' perception of outdoor thermal comfort in informal urban fabric of warm humid climates as well as coping strategies, thermal neutrality, thermal preference and comfort limits are necessary. Addressing these areas will not only further our knowledge of thermal comfort but also bring forward key items of policy implications on the upgrading of informal settlements.

Funding Information This research was supported by the Swedish International Development Agency (SIDA). Open access funding provided by Lund University.

Open Access This article is distributed under the terms of the Creative Commons Attribution 4.0 International License (http:// creativecommons.org/licenses/by/4.0/), which permits unrestricted use, distribution, and reproduction in any medium, provided you give appropriate credit to the original author(s) and the source, provide a link to the Creative Commons license, and indicate if changes were made.

\section{References}

Abbott J (2002) An analysis of informal settlement upgrading and critique of existing methodological approaches. Habitat Int 26(3):303-315

Ahmed KS (1994) A comparative analysis of the outdoor thermal environment of the urban vernacular and the contemporary development: case studies in Dhaka. In: Etzion Y, E. E, Meir IA, Pearlmutter D (eds) 11th PLEA International Conference. The Desert Architecture Unit, Ben-Gurion Univ. of the Negev, Israel, pp 341-348

Ahmed KS (2003) Comfort in urban spaces: defining the boundaries of outdoor thermal comfort for the tropical urban environments. Energy Build 35:103-110

ASHRAE (2004) ASHRAE standard 55-2004, thermal environmental conditions for human occupancy. American Society of Heating, Refrigerating and Air-Conditioning Engineers, Inc., Atlanta

Assis ESd, Frota AB (1999) Urban bioclimatic design strategies for tropical city. Atmos Environ 33:4135-4142

Augustijn-Beckers E-W, Flacke J, Retsios B (2011) Simulating informal settlement growth in Dar es Salaam, Tanzania: an agent-based housing model. Comput Environ Urban Syst 35:93-103

Blazejczyk K, Epstein Y, Jendritzky G, Staiger H, Tinz B (2012) Comparison of UTCI to selected thermal indices. Int $\mathrm{J}$ Biometeorol 56:515-535

Chen L, Ng E (2012) Outdoor thermal comfort and outdoor activities: a review of research in the past decade. Cities 29:118-125

Chen L, Wen Y, Zhang L, Xiang W-N (2015) Studies of thermal comfort and space use in an urban park square in cool and cold seasons in Shanghai. Build Environ 94:644-653

Cheng V, Ng E, Chan C, Givoni B (2012) Outdoor thermal comfort study in a sub-tropical climate: a longitudinal study based in Hong Kong. Int J Biometeorol 56:43-56

Cohen P, Potchter O, Matzarakis A (2013) Human thermal perception of coastal Mediterranean outdoor urban environments. Appl Geogr 37: $1-10$
De B, Mukherjee M (2018) Optimisation of canyon orientation and aspect ratio in warm-humid climate: case of Rajarhat Newtown, India. Urban Clim 24:887-920

Emmanuel R, Johansson E (2006) Influence of urban morphology and sea breeze on hot humid microclimate; the case of Colombo, Sri Lanka. Clim Res 30:189-200

Emmanuel R, Rosenlund H, Johansson E (2007) Urban shading - a design option for the tropics? A study in Colombo, Sri Lanka. Int J Climatol 27:1995-2004

Erell E, Pearlmutter D, Williamson T (2010) Urban microclimate: designing the spaces between buildings. Routledge, London

Fanger PO (1972) Thermal comfort. McGraw-Hill, New York

Hirashima SQdS, Assis ESd, Nikolopoulou M (2016) Daytime thermal comfort in urban spaces: a field study in Brazil. Build Environ 107: 245-253

Hofmann P, Strobl J, Blaschke T, Kux H (2008) Detecting informal settlements from QuickBird data in Rio de Janeiro using an objectbased approach. In: Blaschke T, Lang S, Hay GJ (eds) Objectbased image analysis. Lecture notes in geoinformation and cartography. Springer, Berlin

Huang T, Li J, Xie Y, Niu J, Mak CM (2017) Simultaneous environmental parameter monitoring and human subject survey regarding outdoor thermal comfort and its modelling. Build Environ 125:502-514

Huchzermeyer M (2004) From "contravention of laws" to "lack of rights": redefining the problem of informal settlements in South Africa. Habitat Int 28:333-347

Hwang R-L, Lin T-P (2007) Thermal comfort requirements for occupants of semi-outdoor and outdoor environments in hot-humid regions. Archit Sci Rev 50:357-364

Hwang R-L, Lin T-P, Cheng M-J, Lo J-H (2010) Adaptive comfort model for tree-shaded outdoors in Taiwan. Build Environ 45:1873-1879

ISO (2005) International standard 7730. Ergonomics of the thermal environment - analytical determination and interpretation of thermal comfort using calculation of the PMV and PPD indices and local thermal comfort criteria. International Standard Organization, Geneva

Johansson E (2006) Urban design and outdoor thermal comfort in warm humid climates: Studies in Fez and Colombo, Housing development and management. Lund University, Lund, p 237

Johansson E (2016) Urban thermal comfort in the tropics. In: Emmanuel $\mathrm{R}$ (ed) Urban climate challenges in the tropics - rethinking planning and design opportunities. Imperial College Press, London

Johansson E, Emmanuel R (2006) The influence of urban design on outdoor thermal comfort in the hot, humid city of Colombo, Sri Lanka. Int J Biometeorol 51:119-133

Johansson E, Yahia MW (2012) Improving outdoor thermal comfort in warm-humid Guayaquil, Ecuador through urban design, 8th International Conference on Urban Climate (ICUC-8), Dublin, Ireland, 6-10 August

Johansson E, Spangenberg J, Gouvêa ML, Freitas ED (2013) Scaleintegrated atmospheric simulations to assess thermal comfort in different urban tissues in the warm humid summer of São Paulo, Brazil. Urban Clim 6:24-43

Johansson E, Thorsson S, Emmanuel R, Krüger E (2014) Instruments and methods in outdoor thermal comfort studies - the need for standardization. Urban Clim 10:346-366

Johansson E, Yahia MW, Arroyo I, Bengs C (2018) Outdoor thermal comfort in public space in warm-humid Guayaquil, Ecuador. Int $\mathrm{J}$ Biometeorol 62:387-399

Kakon AN, Mishima N, Kojima S (2009) Simulation of the urban thermal comfort in a high density tropical city: analysis of the proposed urban construction rules for Dhaka, Bangladesh. Build Simul 2: 291-305

Kakon AN, Nobuo M, Kojima S, Yoko T (2010) Assessment of thermal comfort in respect to buildings height in high-density city in the tropics. Am J Eng Appl Sci 3:545-551 
Knez I, Thorsson S (2006) Influences of culture and environmental attitude on thermal, emotional and perceptual evaluations of a public square. Int J Biometeorol 50:258-268

Knez I, Thorsson S (2008) Thermal, emotional and perceptual evaluations of a park: cross-cultural and environmental attitude comparisons. Build Environ 43:1483-1490

Kombe WJ (1995) Formal and informal land management in Tanzania: The case of Dar es Salaam City. Spring Center, Dortmund

Kottek M, Grieser J, Beck C, Rudolf B, Rubel F (2006) World map of the Köppen-Geiger climate classification updated. Meteorol Z 15:259263

Krüger EL, Minella FO, Rasia F (2011) Impact of urban geometry on outdoor thermal comfort and air quality from field measurements in Curitiba, Brazil. Build Environ 46:621-634

Kruger E, Drach P, Emmanuel R, Corbella O (2013) Assessment of daytime outdoor comfort levels in and outside the urban area of Glasgow, UK. Int J Biometeorol 57:521-533

Kruger E, Drach P, Broede P (2017) Outdoor comfort study in Rio de Janeiro: site-related context effects on reported thermal sensation. Int J Biometeorol 61:463-475

Li K, Zhang Y, Zhao L (2016a) Outdoor thermal comfort and activities in the urban residential community in a humid subtropical area of China. Energy Build 133:498-511

Li X, Lv Z, Hijazi IH, Jiao H, Li L, Li K (2016b) Assessment of urban fabric for smart cities. IEEE Access 4:373-382

Lin T-P (2009) Thermal perception, adaptation and attendance in a public square in hot and humid regions. Build Environ 44:2017-2026

Lin TP, Matzarakis A (2008) Tourism climate and thermal comfort in Sun Moon Lake, Taiwan. Int J Biometeorol 52:281-290

Lin T-P, Matzarakis A, Hwang R-L (2010) Shading effect on long-term outdoor thermal comfort. Build Environ 45:213-221

Lin T-P, de Dear R, Hwang R-L (2011) Effect of thermal adaptation on seasonal outdoor thermal comfort. Int J Climatol 31:302-312

Lin T-P, Tsai K-T, Hwang R-L, Matzarakis A (2012a) Quantification of the effect of thermal indices and sky view factor on park attendance. Landsc Urban Plan 107:137-146

Lin T-P, Tsai K-T, Liao C-C, Huang Y-C (2012b) Effects of thermal comfort and adaptation on park attendance regarding different shading levels and activity types. Build Environ 59:599-611

Lin C-H, Lin T-P, Hwang R-L (2013) Thermal comfort for urban parks in subtropics: understanding visitor's perceptions, behavior and attendance. Adv Meteorol 2013:1-8

Liu W, Zhang Y, Deng Q (2016) The effects of urban microclimate on outdoor thermal sensation and neutral temperature in hot-summer and cold-winter climate. Energy Build 128:190-197

Lucchese JR, Mikuri LP, de Freitas NVS, Andreasi WA (2016) Application of selected indices on outdoor thermal comfort assessment in Midwest Brazil. Int J Energy Environ 7:291-302

Lusugga Kironde JM (2006) The regulatory framework, unplanned development and urban poverty: findings from Dar es Salaam, Tanzania. Land Use Policy 23:460-472

Makaremi N, Salleh E, Jaafar MZ, GhaffarianHoseini A (2012) Thermal comfort conditions of shaded outdoor spaces in hot and humid climate of Malaysia. Build Environ 48:7-14

Ndetto EL, Matzarakis A (2013) Effects of urban configuration on human thermal conditions in a typical tropical African coastal city. Adv Meteorol 2013:1-12

Ndetto EL, Matzarakis A (2016) Assessment of human thermal perception in the hot-humid climate of Dar es Salaam, Tanzania. Int J Biometeorol 61:69-85

Ng E, Cheng V (2012) Urban human thermal comfort in hot and humid Hong Kong. Energy Build 55:51-65

Nikolopoulou M (2011) Outdoor thermal comfort. Front Biosci S3:15521568
Nikolopoulou M, Steemers K (2003) Thermal comfort and psychological adaptation as a guide for designing urban spaces. Energy Build 35: 95-101

Nikolopoulou M, Baker N, Steemers K (2001) Thermal comfort in outdoor urban spaces: understanding the human parameter. Sol Energy 70:227-235

Oke TR (1981) Canyon geometry and the nocturnal urban heat island: comparison of scale model and field observations. Int J Climatol 1: 237-254

Potchter O, Cohen P, Lin TP, Matzarakis A (2018) Outdoor human thermal perception in various climates: a comprehensive review of approaches, methods and quantification. Sci Total Environ 631-632: 390-406

Qaid A, Ossen DR (2015) Effect of asymmetrical street aspect ratios on microclimates in hot, humid regions. Int J Biometeorol 59:657-677

Richards R, O'Leary B, Mutsonziwa K (2006) Measuring quality of life in informal settlements in South Africa. Soc Indic Res 81:375-388

Rodríguez-Algeciras JA, Gómez Consuegra L, Matzarakis A (2016) Spatial-temporal study on the effects of urban street configurations on human thermal comfort in the world heritage city of CamagüeyCuba. Build Environ 101:85-101

Rodríguez-Algeciras J, Tablada A, Matzarakis A (2017) Effect of asymmetrical street canyons on pedestrian thermal comfort in warmhumid climate of Cuba. Theor Appl Climatol 133:663-679

Sharmin T, Steemers K, Matzarakis A (2015) Analysis of microclimatic diversity and outdoor thermal comfort perceptions in the tropical megacity Dhaka, Bangladesh. Build Environ 94:734-750

Shih WM, Lin TP, Tan NX, Liu MH (2017) Long-term perceptions of outdoor thermal environments in an elementary school in a hothumid climate. Int J Biometeorol 61:1657-1666

Sobreira F, Gomes M (2001) The geometry of slums: boundaries, packing and diversity. University College London, London

Spagnolo J, de Dear R (2003) A field study of thermal comfort in outdoor and semi-outdoor environments in subtropical Sydney, Australia. Build Environ 38:721-738

Tan Z, Lau KK-L, Ng E (2017) Planning strategies for roadside tree planting and outdoor comfort enhancement in subtropical highdensity urban areas. Build Environ 120:93-109

Trindade da Silva F, Engel de Alvarez C (2015) An integrated approach for ventilation's assessment on outdoor thermal comfort. Build Environ 87:59-71

Tung C-H, Chen C-P, Tsai K-T, Kántor N, Hwang R-L, Matzarakis A, Lin T-P (2014) Outdoor thermal comfort characteristics in the hot and humid region from a gender perspective. Int J Biometeorol 58(9): 1927-1939

UN Habitat (2016) World cities report 2016, Ending urban poverty: improving the lives of slum dwellers. UN Habitat, Nairobi, p 57

Vanos JK, Warland JS, Gillespie TJ, Kenny NA (2010) Review of the physiology of human thermal comfort while exercising in urban landscapes and implications for bioclimatic design. Int J Biometeorol 54:319-334

Villadiego K, Velay-Dabat MA (2014) Outdoor thermal comfort in a hot and humid climate of Colombia: a field study in Barranquilla. Build Environ 75:142-152

Watanabe S, Ishii J (2016) Effect of outdoor thermal environment on pedestrians' behavior selecting a shaded area in a humid subtropical region. Build Environ 95:32-41

Watanabe S, Nagano K, Ishii J, Horikoshi T (2014) Evaluation of outdoor thermal comfort in sunlight, building shade, and pergola shade during summer in a humid subtropical region. Build Environ 82:556565

Xi T, Li Q, Mochida A, Meng Q (2012) Study on the outdoor thermal environment and thermal comfort around campus clusters in subtropical urban areas. Build Environ 52:162-170

Yahia MW, Johansson E, Thorsson S, Lindberg F, Rasmussen MI (2018) Effect of urban design on microclimate and thermal comfort 
outdoors in warm-humid Dar es Salaam, Tanzania. Int J Biometeorol 62(3):373-385

Yang S-R, Lin T-P (2016) An integrated outdoor spaces design procedure to relieve heat stress in hot and humid regions. Build Environ 99: 149-160

Yang F, Lau SSY, Qian F (2011) Thermal comfort effects of urban design strategies in high-rise urban environments in a sub-tropical climate. Archit Sci Rev 54:285-304

Yang W, Wong NH, Jusuf SK (2013a) Thermal comfort in outdoor urban spaces in Singapore. Build Environ 59:426-435

Yang W, Wong NH, Zhang G (2013b) A comparative analysis of human thermal conditions in outdoor urban spaces in the summer season in Singapore and Changsha, China. Int J Biometeorol 57:895-907
Yin J, Zheng Y, Wu R, Tan J, Ye D, Wang W (2012) An analysis of influential factors on outdoor thermal comfort in summer. Int $\mathrm{J}$ Biometeorol 56:941-948

Zeng Y, Dong L (2015) Thermal human biometeorological conditions and subjective thermal sensation in pedestrian streets in Chengdu, China. Int J Biometeorol 59:99-108

Zhang Y, Xiaohan D, Yurong S (2017) Effects of street canyon design on pedestrian thermal comfort in the hot-humid area of China. Int $\mathbf{J}$ Biometeorol 61:1421-1432

Zhang Z, Zhang Y, Jin L (2018) Thermal comfort in interior and semiopen spaces of rural folk houses in hot-humid areas. Build Environ 128:336-347 